\title{
The Cause and Strategy of Oral Communication Barriers in Business English
}

\author{
Wei Xie \\ Tianhe College Of Guangdong Polytechnic Normal University, Guangzhou, 510540, China
}

645321570@qq.com

Keywords: Foreign trade, spoken English, barrier, strategy

\begin{abstract}
With the rapid development of cooperation between countries, as the most basic way of communication, foreign trade oral English becomes more and more important in international trade activities. Because of the difference in mode of thinking and habit of representation between Chinese and Western, as well as the interference of mother-tongue, the cause of oral communication barriers in business English make successful transaction is becoming more and more difficult. First of all, the paper introduces the present situation of oral communication barriers in business. Secondly, from the imperfection of Chinese education, the lack of language environment, the different culture between Chinese and Western countries, and the personal problem of learners to expound the causes of obstacles, and finally, based on the causes of the barriers, analysis the coping strategies.
\end{abstract}

\section{Introduction}

English, as a universal language in the world, is becoming more and more important with the development of international politics, economics and cultural communications and co-operations. With the rising of Chinese politics and economic power in recent years, especially since joining world trade organization, China's economic continue to opening to the outside world with an unheard-of depth and width, increasingly integrating into the economic globalization and regionalization, the economic business of international communicates also more and more multifarious. However, because of the difference in mode of thinking and habit of representation between Chinese and Western, as well as the interference of mother-tongue, the cause of oral communication barriers in business English make successful transaction is becoming more and more difficult. This paper analyses the causes of oral communication barriers in business English, and bring forth the corresponding countermeasures, hope to helpful for the study of oral business English.

\section{The Present situation of oral communication barriers in business}

Foreign trade English refers to the English be used in production of goods or services provides by a country and another country to produce goods or services provides by the cross-border trading activities. Also calling economic and trade English, including all kinds of English documents in import and export trade company, such as business letters, contracts, documents, product specifications and all kinds of documents, etc. The element of foreign trade English is accuracy. International trade activities have a high requirement of the foreign personnel, not only require good English proficiency, also ask them to master the specialized terms and regulations. All formal documents and mails must be the correct meaning, and must not be used in a way that can be misleading.

Speaking is an ability to use spoken language to express ideas and make oral contacts with others. It is get the information by listening and reading, on this basis to process and recombine, and it has been given new content, then output to accomplish the communicative. Although foreign trading staffs can use English to communicate with foreigners, but habit and form are influenced by traditional Chinese culture, foreigners also have no notion of what is Chinese communication skill and pragmatic tradition, resulting in some mistakes and conflicts. Therefore, to research how to 
improve foreign trading staffs' cross-cultural oral communication ability is plays a great role in the development of international trade.

\section{The cause of oral communication barriers in business English}

\subsection{The defection of Chinese education}

In recent years, despite foreign trade English had reformed in teaching philosophy, teaching content still focus on explain and emphasis vocabulary and grammar, especially neglect to cultivate the ability of oral English for foreign trade. Teaching materials of foreign trade oral class are outdate, and curricular contents are lack of innovate, doesn't have enough practice situations. There is no attractive to students, a oppressive class atmosphere caused worse at learning. Most of the oral English classes for foreign trade continue to use the teacher who is control students, that is teacher-centered teaching model. Students doesn't have enough time to practice, lack of training the ability to use language and communicate with others, it limits students to develop theirs activity and creativity. In spoken English class, large classes have been common in most of schools, too much students so that they cannot get enough classroom training, and few teaching hours, all of that are restrict the effective improvement for the ability of the English oral communication.

\subsection{The lack of foreign language environment}

One can never learn to master a language without environment, students are live in native language. Lack of foreign trade language environment is restricting the learning in the foreign trade spoken English. Staffs are come from different countries in international trade activities, the barriers of context also influence communication in foreign trade spoken English. Here according to several missing aspects in foreign trade to analyze, hope to based on the problems to table a concrete proposal to fill the gaps. Students are usually meet with difficulties and troubles when it comes to studying English under the inferences of their mother tongue. Usually, these interferences will show up as the phonetic laws of Chinese instead of phonetic rules of English directly. Students tend to use the Chinese-style expression under the distraction, easily occur interference on word order, interference on grammatical structure, disturbance on diction and interference on presentation. For example, when student want to expressing the profit of order is very low, Chinese-English will say: Our profit is very low in this order. But native English will say: Our margin is very thin in this order. To describe profit is low, low profit is current, there is no mistake between grammar and meaning. But Americans usually tend to use margin to instead of profit and thin instead of low or less. However, when foreign trade staff is discussing payment way with client, if client ask for payment at sight, There is no doubt that explain to client this is our company hard and fast rule, while company had stipulated make out letter of credit in big purchases. If use the Chinese way of thinking to translate, it could be hard rule, client cannot understand what meaning of sentence. In that case, also cannot use company rule or company policy to describe, because client will feel this is a flexible policy. So, there is a fixed collocation in foreign trade English is hard and fast rule. It can be expressed as: sorry, Michael, Sorry, Michael, we could only accept L/C with deposit. It's our hard and fast rule.

At present, there are not as many English teachers to teach all Oral English classes regarding foreign trade. Many teachers also influenced by Chinese traditional thought, spent most of vigor and time to introduce background of foreign trade. However, there are a few chances for students to take part in role plays about foreign trade, even jump this step because insufficient time. Out of class, most of teachers and students are lose all touch with English, always speaking Chinese. What's more, it is no need to use foreign trade English in daily life, and there is a strong barrier for students is few practicing chances. It is difficult for them to improve the ability of foreign trade spoken English.

\subsection{The differences between Chinese and Western cultures}

There is a big gap between Chinese and Western culture, especially the different on thinking way directly affect cross-cultural communication and resulting oral communication barriers in business English. Because of the influenced by different society, history, cultural background, there are distinct differences between the thinking patterns of Chinese and Western. The thinking way of Westerners is linearity. First of all, he will put forward some views and opinions, directly point to 
understand the theme of the talk. The next step is discussing the background, reasons, teams and conditions or evidence. Besides, the thinking way of Chinese is circular. People accustomed to point the theme indirectly in general, tend to start from outside to explain the problem with different aspects. Firstly, people will illustrate the background and reasons of problem, next to the conclusion. Because of Chinese are used to doing step by step, always put the most important information last. For example, a few of staffs harangue to introduce the company and factory first, introduce the information of product what the client need at the end. According to the habits and thinking patterns of occidental, the first step of talking should be emphasize the product and then explain other details. After know the thinking pattern of oriental, occidental will read the backmost information when they read the business letters.

There is a big gap between different culture of different countries and nations. The barriers of oral communication in business English are easily to produce by pay no attention to avoidant of vocabulary and circumbendibus of using word.

In Eastern cultures, people tend to avoid looking other directly, aim to show polite and respectful. On the contrary, Westerners like to look at the other person in the eyes when they are talking to show respectful and single-hearted. Speaker should be look back to the listener, in order to know the reaction from listener in time and show himself confident and sincerity.

The culture conflicts and barriers between mother tongue and English also show up as the number, color, the interests on animals and plants, daily life terminologies, taboo topics (income, age, weight, religion, etc.). Besides, the difference of culture is caused by different values, social regulations, national character and thinking patterns. For example, Chinese foreign trade staff appointed time to business negotiation with Dubai's trade representative. Both side were locked in a stalemate about price clause. Suddenly, opposite side asked for newspaper, while he begged Chinese representative on his knees when staff is wondered why he wanted it. Chinese representative was quite taken aback by the action and thought him kneeled down in order to make a deal, raised client up immediately. Never thought, client was angry and refused to stand up. Finally, client was terminates the deal with Chinese and lead to failure in communication.

In this business activity case, Chinese representative was blind to the culture background of Middle East country. In fact, most of Arabian believes in Islam, they should worship at regular time at least 5times every day. Once that time limit's up, most of them will stop work and pray for the place where the Mecca is. And, Chinese representative and Mecca are same direction, he lifted him up without knowing it, and then lead to client feels the religion was offended. Otherwise, Dubai's trade representative also was unfamiliar with the meaning of kneel is humiliation and yield in Chinese culture. The Chinese staff do not want to make him feel humiliated, helped him up quickly, prevented them pray unintentional. Cultural conflicts caused by they broke religious and lead to cause the barriers of oral communication in business English.

\section{The strategies of barriers}

Base on the type of barriers above to analyzes the barriers and proposes related strategies, start from education, social environment and student themselves to solve the problem practically.

\subsection{In education}

This paper will analyze the teaching present situation of foreign trade oral English systematically, at the same time processing to improve the teaching way and achieve oral English teaching effectively.

The class of oral business English is an important course, it is necessary to open the class of oral business English. In the class of oral business English, not only want to reserve proprietary words and expressions in foreign trade, but also want to training and practice frequently. Students should be step by step to master the speaking skills and become a expert to work on interpreter in foreign trade and easily adapt and change according to the situation when they negotiate the business with clients.

School can usually organize extracurricular activities about oral business English, pay attention to cultivate students can understand the real intention and attitude of speaker, and the skill of 
understand the content what speaker want to express and related background. For example, English corner had hold a party and the theme is foreign trade, students face to face communicate with stranger just like to find the client, it cultivate the brave of students to speak English and their interest were inspired. And it can help students to come to a better understand of topics, improve the oral expression ability of students effectively at the same time. School also can organize role plays and the theme id about oral business English. Such as changing roles: three students make a group, one speaks Chinese, one speaks English acting as the foreigner, and one acts an interpreter. After practice a scene and then change again. This is a good interpreting training method and is good for studying from one another. Students can find their shortcomings in these speaking practices and raise awareness can help them to improve strain capacity and skill.

\subsection{The construction of the foreign language environment}

The purpose of learning foreign trade English is communicate with foreign merchants in English and use the knowledge of foreign trade. For the salesman of foreign trade, it is the most important to improve the oral English. Language environment make a great influence to the improvement of oral English, it provides the requirement and course to oral English. Such as simulate, study, training and practice, etc.

4.2.1 The creation of English village

English village is the updated version of localized studied abroad, the teaching mode of English village is founded a open and full English learning environment for Chinese college students. All of people in English village must be speaking English, enhance the effect of study by a thick atmosphere of language learning and learning pattern with sense of obligation. In here, foreign teachers are living and learning all day with students, foreign teachers are make a good use in the process of the spread Western culture. Students are playing an active role in talking with teachers; it will be easily to acquaint the Western culture. Teaching highly targeted English course to students at the same time, such as cross-cultural communication, business English, tourism English, movie English, break away from regular textbook knowledge and let the students studying in a relax atmosphere. Furthermore, English village have all kinds of funny activities to training students all day, such as party, English corner, English short drama and talent show, etc. In the language environment with full English and physical situation, the students were worried about make mistakes and laugh by other students have to speaking English, after training a period of time, students will more and more confident and the improvement of listening will have a obviously increase.

The classes in Oral Business English at the English village tends to pay attention to the students' completion of practical task, especially the live simulation tasks are close to real situation of oral English. The tasks including classroom discussion, group activities, scenario simulation, spontaneous dialogue, thesis statement, symposium, debate, business negotiation, business role play, simulative entrepreneurial activities, case studies activity and business studies activity, etc. The key of the tasks is promoted a closest to the truth business English learning atmosphere; improve the each quality and improvisation of students quickly. Students are copy the right behaviors and communicate patterns in scene observation and simulate experience, cultivate their team spirit and cooperation at the same time.

4.2.2 More practice opportunity

School should develop the foreign teachers affect in the process of the spread Western culture if had foreign teachers teaching in the school. Encourage students communicate with foreign teachers directly, attend more foreign teachers' lectures. Teach by personal example as well as verbal instruction must be influence character by environment for students. Foreign teachers have been deeply influenced by Western culture, employ them to join in the class of foreign language teaching will be easily to arouse the interest of the students. Foreign teachers introduce culture, custom and living habit of his country, meanwhile, is the time for students to understand the culture of teacher's country.

Because of the class time is very limited, students can build more English communicate environment for own without classes. Learners can attempt to take part in twice-yearly Canton Fair, to fine the chance to interpret for foreign merchants. They also can join in the activities just as oral 
business English talk show held by Fob Forum. The talk show covered extensive contents, such as the reception of oversea clients, reception of exhibition, visit, negotiation, business trip and interview, etc. At ordinary times, students can attend to the business lectures of foreign experts, to understand the daily life of United States and in England by all kinds of ways, to build a English environment for own. As long as students master foreign trade English with four aspects of basic capabilities (listening, saying, reading, writing), through continuous learning and communicating, absorb the Western culture, can be cross-business-cultural communicative with foreigners successfully.

The level of foreign trade oral English can be improving sharply in social practice. Students can touch some practical work of foreign trade in the practice. Such as receive foreign clients in English at the reception desk, help the foreign manage to negotiate at the conference, etc. In this environment, student not only can use the theoretical knowledge of foreign trade and basic skill of oral English, but also can training the ability of analyze and solve problem independently, link theory with practice, improve the social skill of students and lay a solid foundation for students when go into the workplace.

\subsection{In culture}

In the construction of culture, students should pay attention to cultivate their inter-cultural communicative awareness, increase the contact with Western culture, also should master the knowledge of international trade and convention in international business at the same time. To better resolve conflicts caused by different of thought pattern and culture background.

4.3.1 Cultivate the awareness of Cross-cultural communication

Cultivate the awareness and ability of inter-cultural communicative is a requirement of the development of the times, it became an important bridge and link of exchange and cooperation between countries. When students are studying Oral English as a Foreign Trade, they should pay more attention to culture background and connotation of language in order to cultivate their own cross-cultural awareness in daily life.

Students can from a variety of sources to touch the information of Western culture. To collect some goods and pictures about English-speaking countries, it can help students to realize the arts, history and local conditions and customs of foreign countries. If there is a condition, can also read some English version of the summary, magazine and comment of foreign countries, add to understand of English culture. Furthermore, watch English film, program and video can give an intuitive appreciation to students; they are influenced by what one constantly sees and hears. At ordinary times, students can attend the lectures about cultural difference of educationist from all over the world, learn from a variety of language environment and expand the vision of Western culture, and improve their practical operating ability and cultivate inter-cultural communicative awareness. Thus, to improve inter-cultural communicative ability.

4.3.2 Combine the thinking between Chinese and Western

The cultural backgrounds are different in China and the West, which brings about different ways of thinking and different organizing principles of discourse. To sum up, comprehensive mode make Chinese emphasize the many becomes one and analytical mode make Foreigner accustomed to the one becomes many. Therefore, college students should according to logic mode of thinking of English language to compose the statement in the process of using spoken English. And adjust based on statement structure, in order to accord thinking patterns and expression custom with others. At the same time, students should notice the integration of cultural factors, to understand, taste and respect each other's culture. In peacetime, students can teach the Westerners how to describe the thing. Americans are always by my description of space and external, from the inside and the tables. Just like describe the address. The Chinese people just the opposite; always put the most important information last, just like describe the address from big to small. Describe as the time when the Americans first come out the most important things to say, and then say something foils. The Chinese are described according to nature of time sequence. For example, American will say, I'm not going to visit the factory since it's raining. Chinese people will say, because of raining outside now, so I am not going to visit the factory. There is a hard way to change the thinking pattern of Chinese student, but after training student can mix the thinking way together. 


\subsubsection{Master the principles of international trade}

With the rapid development of international trade and joined the World Trade Organization, it will more and more popular of the application of international trade customs in our country. A qualified foreign trade staff, should be master the basic theory and knowledge of international trade, realize the socioeconomic status of main countries and area, and know the international trade rules and regulations. A person have to possess these basic skills can work on foreign trade in English better.

\section{Conclusion}

The paper from the defection of Chinese education, the lack of language environment, cultural differences between Chinese and Western Countries and language learners' personal problems to illustrate the cause of oral communication barriers in business English, and advice for each reason. In education, teacher should find the problems of students in oral communication in foreign trade actively, and adopt corresponding strategies to guide students to remove the obstacles. In addition, teacher should create and catch the chance to let the students communicate with others in business English boldly as much as possible, training their English integrated applied abilities. In society, school and foreign trade enterprise should strengthening cooperation and exchange, provide more practical opportunities for students, promote a foreign trade oral English environment for students as far as possible. Students also need to find and touch on his own initiative where can create a foreign trade atmosphere for themselves. Overcome psychological barrier and develop all kinds of ability. In any case, they have to foreign trade staff requirements and standards to themselves. Understand the cultural differences between Chinese and Western Countries in daily life, learn to use the thinking pattern of Western, reduce the gap of cultural difference as much as possible.

The purpose of Oral Business English is using different language to commercial exchange between the people in different culture. The barriers of oral communication in business English caused by many factors, this paper focus on educational method, language environment, cultural differences and student themselves to analyze the barriers. Still should research other reasons what can cause to the barrier. Hope the strategies advice by this paper can help to improve the level if foreign trade oral English, to promote the development of international trade in a healthy way.

\section{Acknowledgement}

This paper is a research result of Education Department of Guangdong Province, that is based o $\mathrm{n}$ the teaching quality and teaching reform construction project of "the training base of oral English

" in undergraduate colleges of Guangdong Province in 2014, (No.97 Higher documents of Educatio n Department of Guangdong Province in 2014).

\section{References}

[1] Wei Xie. The Study of Students' Problems in Spoken English at the English Village. Atlantis Press. 2015(32): 143-146.

[2] Jinyu Dong, and Jiexiu Liu. “Analysis of Practical Business English Talent Teaching Mode Under Cross-Cultural Communication”. Cross-Cultural Communication 6(2015):21-26.

[3] Ping Liu. “On Oral English Teaching for Chinese English Majors from a Constructivist Perspective”. Studies in Literature and Language 3(2012):133-138. 